forensic services, most of these units function in isolation and are unaware of similarities and differences of practice. The recent articles (Zigmond, 1995; Dix, 1995) highlight the most relevant issues.

We propose to have a one day meeting of senior PIC staff to discuss important issues raised by Zigmond (e.g. high dose medication, standards of care, criteria for admission) and any other relevant issues.

We would be happy if those interested should write to us including a brief description of their unit.

Dix. R. (1995) A nurse-led psychiatric intensive care unit. Psychiatric Bulletin. 19. 285-287.

ZIGMOND. A. (1995) Special Care wards: Are they special?

Psychiatric Bulletin, 19, 310-312.

M. Dominic Beer, CARol Paton and Stephen PereIRA, Specialist Mental Health Directorate, Bracton and Stansfield Clinics, Bexley Hospital, Old Bexley Lane, Bexley, Kent DA5 $2 B W$

\section{Management training at senior registrar level}

Sir: The Collegiate Trainees Committee Report on management training in psychiatry (Psychiatric Bulletin, April 1995, 19, 264-266) states that there has been much discussion about management training at senior registrar level. Unfortunately this increasingly important aspect of higher professional training remains underdeveloped. In an attempt to plug this gap the Senior Registrars' Forum (supported by Lundbeck) has expanded to provide regional one-day workshops in addition to established residential workshops. The one-day workshops aim to cover a variety of management topics according to local needs. Recent workshops have covered government strategy, information technology, delegation and leadership skills.

For further information about the Senior Registrars' Forum, forthcoming events and future workshops, please contact the Senior Registrars' Forum, c/o Sunningdale House, Caldecotte Lake Business Park, Caldecotte, Milton Keynes MK7 8LF.

JoNATHAN I. BISSON, Lecturer, University of Wales College of Medicine, Heath Park, Cardiff CF4 4XN and MARTIN BAGGALEY, Senior Lecturer, Royal Army Medical College, Millbank, London SW1 4JT

\section{An ethical dilemma in child psychiatry}

Sir: Reading the case description (Psychiatric Bulletin, February 1995, 19, 84-86) of an eight-year-old, otherwise normal girl without prior psychiatric or psychologic disturbance, who developed a syndrome of negativism, mutism, incontinence, muscle weakness, with failure to feed following two 'viral' infections compels our consideration of a systemic basis for her condition. We consider it likely that this patient suffered from a postviral encephalitis with resultant syndrome of catatonia. The prolonged and persistent course of disability may have been encouraged by the failure to consider proper interventions for such a disorder.

On a descriptive level, the prominence of motor signs suggests that the syndrome may meet the definition of catatonia, usually defined by abnormal motor movements accompanying a mental disorder (Taylor, 1990). Stupor, negativism, mutism, rigidity, and posturing are frequently identified signs. A variety dominated by excitement is recognised. Most reviewers see catatonia as a functional state which seems not to result from structural brain changes. For decades, catatonia has been considered only as a subtype of schizophrenia, as the DSM-III and DSM-III-R classifications compelled the classification of patients manifesting the motor signs of catatonia into the single class of "schizophrenia, catatonic type [295.20]". Such a classifaction also prompted treatment with neuroleptic drugs.

For almost three decades, however, authors have described catatonia in patients with affective disorders, especially mania, secondary to systemic disorders, especially lupus erythematosus, infections, and following various neurotoxic agents. Re-consideration of the characteristics and treatment response of patients with the neuroleptic malignant syndrome argues that this syndrome is better considered a type of catatonia rather than a consequence of dopaminergic inhibition (White \& Robins, 1991).

Catatonia is best described as the prominence of at least two motor abnormalities in patients with mental disorder (Taylor, 1990). While detailed treatment studies are lacking, case material argues that the administration of benzodiazepine drugs is the first treatment (Fricchione et al, 1983), and in patients who fail such intervention or who develop the 